\title{
Responsiveness of Service Sector Growth to Financial Development in Nigeria: Evidence from 1981-2019
}

\author{
Henry Ikechukwu Amalu' ${ }^{1}$, Lucy Obiageli Agbasi ${ }^{2}$, Loenard U. Olife ${ }^{3}$, Anthony Okechukwu ${ }^{4}$ \\ ${ }^{I}$ Department of Banking and Finance, University of Nigeria Nsukka, Enugu State, Nigeria \\ ${ }^{2,3}$ Department of Banking and Finance, Enugu State Polytechnic, Enugu, Enugu State, Nigeria \\ ${ }^{4}$ Department of Accountancy, Enugu State Polytechnic, Enugu, Enugu State, Nigeria
}

\begin{tabular}{|c|c|}
\hline Article Info & Abstract \\
\hline $\begin{array}{l}\text { Article history: } \\
\text { Received:15 June } 2021 \\
\text { Revised: } 19 \text { August } 2021 \\
\text { Accepted: } 24 \text { August } 2021\end{array}$ & $\begin{array}{l}\text { Purpose: This paper explores the relationship between financial development } \\
\text { and output of the service sector in Nigeria over the period 1981-2019. It } \\
\text { presents an analysis of the long-run and short-run impacts of financial } \\
\text { development on the performance growth of the service sector, as well as the } \\
\text { cointegration between the variables. }\end{array}$ \\
\hline Keywords: & $\begin{array}{l}\text { Approach/Methodology/Design: We test the time series for stationarity using } \\
\text { Phillips-Perron and Augmented Dickey-Fuller unit root tests. We adopt the }\end{array}$ \\
\hline $\begin{array}{l}\text { Service Sector, } \\
\text { Financial Development, }\end{array}$ & $\begin{array}{l}\text { Auto-Regressive Distributed } \mathrm{Lag}(\mathrm{ARDL}) \text { approach to analyze the } \\
\text { relationship between financial development and service sector performance in }\end{array}$ \\
\hline $\begin{array}{l}\text { Credit to the Private Sector, } \\
\text { Monetization Ratio, } \\
\text { Private Credit }\end{array}$ & $\begin{array}{l}\text { Nigeria. Market capitalization, monetization ratio, and the ratio of credit to } \\
\text { the private sector to GDP represent the indicators of financial development. } \\
\text { Findings: The results of the study show that market capitalization and } \\
\text { monetization ratio have significant positive impacts on service sector output, }\end{array}$ \\
\hline JEL: G32, O16 & $\begin{array}{l}\text { respectively. However, the effect of credit to the private sector on service } \\
\text { sector performance is insignificant and negative. We find no cointegration }\end{array}$ \\
\hline Paper Type : & among the investigated variables; while, the result of the error correction \\
\hline Research Article & $\begin{array}{l}\text { estimation indicates that it takes about two years to restore the long-run } \\
\text { equilibrium after a deviation. In light of the findings made, this paper }\end{array}$ \\
\hline Corresponding Author: & 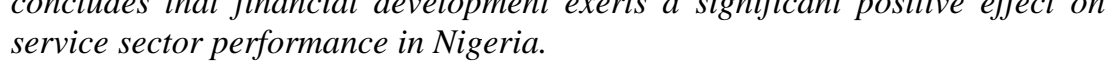 \\
\hline Henry I. Amalu & $\begin{array}{l}\text { Practical Implications: This study is valuable at this period of economic } \\
\text { uncertainties in Nigeria. With input from this paper, policymakers in the }\end{array}$ \\
\hline Email: & $\begin{array}{l}\text { public sector via the formulation and implementation of effective policy } \\
\text { measures such as fiscal measures can channel the benefits of financial sector }\end{array}$ \\
\hline henryik47@gmail.com & $\begin{array}{l}\text { development to the service sector to create an enabling business environment } \\
\text { for the sector, especially as it concerns the provision of private credit to the } \\
\text { sector. } \\
\text { Originality/value: Based on literature review, this paper for the first time } \\
\text { investigated the link between financial development and the performance of } \\
\text { the service sector in Nigeria as defined by the CBN Statistical Bulletin } 2019 \\
\text { edition. }\end{array}$ \\
\hline
\end{tabular}

\section{Introduction}

This paper examines the relationship between financial development and the service sector performance in Nigeria. Several studies on financial sector development and growth nexus maintain the opinion shared by Schumpeter concerning the favourable effect of financial development on output. As argued by Schumpeter, a well-functioning financial sector performs its core targets including savings mobilization, monitoring of managers, facilitation of transactions, efficient distribution of scarce resources among alternative projects, etc. (King \& Levine, 1993; Schumpeter, 2011); and by implication stimulates technological innovation and 
productivity growth. Several studies have extensively researched on financial development and economic growth nexus, while a greater percentage focused on cross-sectional studies (De Gregorio \& Guidotti, 1995; Hermes \& Lensink, 2004; Ductor and Grechyna, 2015; Mollaahmetoğlu and Akçalı, 2019; etc.). Some research work in this category covered both developing and developed countries. Nigeria, an emerging economy in Africa, still wields influence on the continent. Previous studies on financial development in Nigeria concentrated more on the overall economic growth (Bassy \& Effiong, 2020; Iheanacho, 2016; Audu \& Okumoko, 2013; Hashim, 2011; Madichie, Oguanobi, Maduka, \& Ekesiobi, 2014; among others). Given this situation, sectoral analyses become important in the on-going debate to ascertain the level of impact from financial development on identified sectors of the economy in Nigeria.

One of the main and growing sectors of Nigeria's economy is the service sector. It remains the biggest sector of the economy in terms of contribution to the gross domestic product (GDP) as reported by the Central Bank of Nigeria (CBN) Statistical Bulletin 2019 edition. Our nonexhaustive review of past literature has shown that studies on the service sector as it relates to financial development have not been conducted before. We intend to fill this void by examining the extent to which Nigeria's financial sector development has impacted the service sector. To achieve this purpose, we adopt the most recent data on the variables of interest (with the qualities to produce more realistic empirical results) as reported by the identified source.

The recent data on financial development indicators and the service sector adopted reflects the economic fluctuations and other socio-economic developments that occurred in Nigeria in recent times. Previous studies on the related subjects that used outdated data cannot guarantee this vital feature. This research study is written at the right time given the increasing emphasis on the knowledge economy in our contemporary world. Expectedly, the service sector represents the future of Nigeria's economy, if only the drive for human capital development can be pursued with passion and vigor by both the public and private sectors. The statistics has shown that people below 35 years of age constitute more than half of Nigeria's population. These vibrant and digital-savvy young people propel the robust growth recorded in the fintech industry, a fastgrowing arm of the information and communication sub-sector in Nigeria (FinTech Association of Nigeria \& EY, 2020).

The service sector in Nigeria is constituted by thirteen major sub-sectors which include education; trade; accommodation and food services; transportation and storage; information and communication; financial and insurance; arts, entertainment, and recreation; education; real estate, human health and social services; etc. (CBN Statistical Bulletin, 2019). A close look at the growth of the service sector in the past ten years, in terms of its nominal contribution to the gross domestic product (GDP), shows that the sector's volume of output grew by $206 \%$. Some sub-sectors are key to the significant growth recorded by the sector. Between the period 20092019, the three key sub-sectors that led the growth chart in the service sector are trade, information and communication, and real estate. Information and communication came first with a growth rate of $246 \%$ between $2009-2019$. The trade segment of the sector rose by $185 \%$ within the above reference period; while, the real estate sub-sector increased by $142 \%$ within the same

Copyright (C) 2020, Journal of Advanced Research in Economics and Administrative Sciences (JAREAS), Under a Creative Commons Attribution 4.0 International License 
period. The information and communication sub-sector still leads the rest of the services subsectors in the Nigerian economy largely due to increasing foreign and domestic investments in the sub-sector.

In this study, we intend to demystify the role of financial development, albeit empirically, in promoting the economy of the service sector in Nigeria. This way, we will add to the literature on the relationship between the variables of interest as it affects Nigeria.

\section{Methodology and Procedures}

In this study, focus is on the relationship among InSGDP, InMKTC, M2GDP, and InCPSGDP. Given the stated variables, the functional expression of the model becomes:

$\operatorname{InSGDP}_{t}=\beta_{0}+\beta_{1} \operatorname{InMKTC}_{t}+\beta_{2} M 2 G D P_{t}+\beta_{3} \operatorname{InCPSGDP_{t}+\varepsilon _{t}}$

where InSGDP represents the natural logarithm of the services sector divided by GDP; InMKTC stands for the logarithm of market capitalization; M2GDP denotes monetization ratio; InCPSGDP stands for the natural logarithm of credit to the private sector divided by GDP; and, $\boldsymbol{\varepsilon}_{t}$ denotes the error term. We adopt the Auto-Regressive Distributed Lag (ARDL) model as a base level test. The model has some advantages over other regression methods, which include: (a) it permits different lag structures from variables; (b) it allows variables of different stationarity properties, i.e., both stationary and nonstationary variables; and, (c) being a dynamic model, it is less susceptible to autocorrelation and other deficiencies shared by other regression models. As developed by Pesaran and Shin (2001) and cited by Amalu et al. (2020), the ARDL model is defined as

$\phi(\mathrm{L}, p) y_{t}=\sum_{i=1}^{k} \quad \beta_{i}(L, p) x_{i t}+\delta^{\prime} w_{t}+\mu_{t}$

where

$\phi(L, p)=1-\phi_{1} L-\phi_{2} L^{2}-\ldots-\phi_{p} L^{p} \quad$ and

$\beta_{i}(L, p)=\beta_{i 1}+\beta_{i 1} L+\beta_{i 2}+\ldots+\beta_{i q i} L_{i}^{q} i=1,2, \ldots, k$

where $\mathrm{L}$ is a lag operator, and $w_{t}=$ an $\mathrm{s} \times 1$ vector of deterministic variables. The choice for the optimal lag model is determined using Akaike Information criteria (AIC).

We deploy the Bound test to determine cointegration amongst the variables of interest. As advised by Pesaran and Shin (2001), the decision for the Bound test is made using two critical values -- I(0) bound and I(1) bound indicating upper and lower bounds, respectively. The null hypothesis of the Bound test denotes no long-run relationships among the identified variables. The null hypothesis is rejected, if the test statistic is greater than I(1) bound. There is no cointegration, if the test statistic is lower than the $\mathrm{I}(0)$ bound; while, the result becomes inconclusive where the test statistic falls in-between the $\mathrm{I}(0)$ bound and $\mathrm{I}(1)$ bound values.

Copyright (C) 2020, Journal of Advanced Research in Economics and Administrative Sciences (JAREAS), Under a Creative Commons Attribution 4.0 International License 


\section{Data}

We use time series derived from the Statistical Bulletin of the Central Bank of Nigeria (CBN) 2019 edition. The annual data spans from the period 1981 to 2019. The time series are scaled and quantitative data that maintain regular frequency and are secondary. The data are secondary because they are collected from pre-existing sources. The proxies for financial development are market capitalization, monetization ratio, and percentage of credit to the private sector to GDP. As utilized in this study, the dependent variable represents the performance of the services sector divided by the nominal GDP. Other important explanations of the variables are provided below.

Table 1. Descriptive statistics

\begin{tabular}{ccccccccc}
\hline Variable & Mean & Median & Std. Dev & Min. & Max. & JB & Prob. \\
& & & & & & & \\
\hline SGDP & 0.485367 & 0.493600 & 0.052357 & 0.604200 & 0.390700 & 0.657975 & 0.720 \\
& MKTC & 5584.306 & 472.3000 & 7881.275 & 5.000000 & 25890.22 & 8.411388 \\
& 0.014 & M2GDP & 15.185103 & 12.74000 & 5.227466 & 9.150000 \\
25.16000 & 5.314021 & 0.070 & CPSGDP & 1.21231 & 8.210000 & 5.399793 & 5.920000 \\
20.77000 & 6.322956 & 0.042 & & & & &
\end{tabular}

Source: Authors' computation using Eviews software.

Market capitalization as adopted in this paper represents the total value of transactions in the capital market in Nigeria over the specified period. It measures the size, activity, and efficiency of the country's capital market. The capital market is a financial market in which stocks, bonds, and government securities, among other long-term securities, are traded among market participants. The monetization ratio stands for the ratio of broad money to gross domestic product (GDP). It measures the size of a formal financial sector as well as the depth of a financial sector (King \& Levine, 1993). A higher monetization ratio suggests a larger financial sector (Calderon \& Liu, 2003).

Table 2. Correctional matrix

\begin{tabular}{lccc}
\hline Variables & SGDP & MKTC & M2GDP \\
\hline MKTC & 0.622 &
\end{tabular}

$\begin{array}{lrrr}\text { M2GDP } & 0.622 & 0.917 & \\ & & {[5.121]} & \\ & & (0.000) & (0.000) \\ \text { CPSGDP } & 0.657 & 0.876 & 0.967\end{array}$

Note: values in parentheses stand for p-values. T-statistics are shown in braces, while correlation coefficients are unenclosed.

Source: Authors' computation using Eviews software. 
Percentage of private credit to GDP denotes financial institutions' claims on the private sector relative to GDP. Credit to the private sector means the total credits given to the private sector by the financial institutions excluding loans issued to the government-owned establishments. The service sector as used in this paper represents a combination of firms and other business units located in Nigeria that produce services as their end products.

Table 3. Unit root tests results

\begin{tabular}{|c|c|c|c|c|c|c|c|c|}
\hline \multicolumn{2}{|c|}{$\begin{array}{l}\text { Variables } \\
\text { (With Trend) }\end{array}$} & \multicolumn{2}{|c|}{ PP Test } & \multicolumn{2}{|c|}{ (With Trend) } & \multirow{2}{*}{\multicolumn{2}{|c|}{ Critical V }} & \multirow[b]{2}{*}{ Remarks } \\
\hline & PP t-stat & Critica & $\mathrm{ll} \mathrm{V}$ & Remarks & ADF t-stat & & & \\
\hline InSGDP & -5.14 & $-3.54 * *$ & $-4.23 *$ & $\mathrm{I}(1)$ & -5.20 & $-3.54 * *$ & $-4.23 *$ & $\mathrm{I}(1)$ \\
\hline InMKTC & -4.63 & $-3.54 * *$ & $-4.23 *$ & $\mathrm{I}(1)$ & -4.68 & $-3.54 * *$ & $-4.23 *$ & $\mathrm{I}(1)$ \\
\hline M2GDP & -6.87 & $-3.54 * *$ & $-4.23 *$ & $\mathrm{I}(1)$ & -5.86 & $-3.54 * *$ & $-4.23 *$ & $\mathrm{I}(1)$ \\
\hline InCPSGDP & -6.13 & $-3.54 * *$ & $-4.23 *$ & $\mathrm{I}(1)$ & -5.53 & $-3.54 * *$ & $-4.23 *$ & $\mathrm{I}(1)$ \\
\hline
\end{tabular}

Note: * and ** denote statistical significance at the 1\%, 5\% levels, respectively. The PP test utilizes non-parametric correction attributable to Newey and West (1987) to solve possible serial correlation. We select lag truncation for non-parametric correction with the help of automated bandwidth estimator adopting Barlett kernel (Andrews, 1991) Source: Authors' computation using Eviews software.

\section{Descriptive statistics}

Descriptive statistics shown in Table 1 indicate the average of SGDP 0.486 and the ratio's maximum and minimum values as 0.39 and 0.60 , respectively. As indicated in fig. 2 , the service sector's contribution to GDP was at its maximum in 2016. Within the period covered by this study, the service sector, captured as Services in the Bulletin remains the biggest contributor to Nigeria's GDP compared to the other two major sectors, Agriculture, and Industry, as reported by the Bulletin. The mean of MKTC is N5584.306 bn; while the average values of M2GDP and CPSGDP are 15.19 and 11.21, respectively. The series, MKTC and CPSGDP are normally distributed as indicated by the p-values of the Jarque-Bera statistics at the $5 \%$ level.

\section{Results and Discussion}

We examine the variables for unit roots using two unit root tests -- Phillip- Perron unit root test and the Augmented Dickey-Fuller (ADF) unit root test. The Phillip- Perron test is conducted following the Phillips and Perron (1988). For robustness check, we conduct the Augmented Dickey-Fuller (ADF) unit root test as specified by Dickey and Fuller (1981). The results reported in Table 3 show that all the variables of interest are stationary at the first difference, at the $1 \%$ and $5 \%$ levels of significance, respectively. 
Table 4. Long-run elasticities

\begin{tabular}{lcccc}
\hline Variable & Coefficient & Std. Error & t-statistic & P-value \\
\hline InMKTC & 0.103 & 0.040 & 2.543 & 0.019 \\
M2GDP & 0.044 & 0.019 & 2.283 & 0.033 \\
InCPSGDP & -0.287 & 0.198 & -1.449 & 0.162 \\
Intercepts & -0.648 & 0.245 & -2.647 & 0.015 \\
$R^{2}=88 \% ;$ DW stat $=2.1$ & & & \\
RESET F-stat: $0.368(0.777)$ & & & \\
BG F-stat: & 0.372 $(0.774)$ & & \\
Het (White) & F-stat: $0.655(0.783)$ & & & \\
\end{tabular}

The selected model in the ARDL model $(2,3,3,1)$.

Source: Authors' computation using Eviews software.

The results of the diagnostic tests presented in the lower part of Table 4 show the F-statistic of 0.368 for the Ramsey RESET test, significant at the 5\% level. It is an indication that the ARDL model is correctly specified. DW stat of 2.1 that shows no evidence of autocorrelation is supported by the result of a higher test order, the Breusch-Godfrey LM test as shown in Table 4. Also, there is no evidence of heteroskedasticity as revealed by the Breusch-Pagan-Godfrey test result.

Following the results of the linear association test presented in Table 2, this paper reports the correlational relationships that exist among the studied variables. SGDP and MKTC share a significant correctional relationship at the 5\% level of significance. Similarly, a statistically significant correction is found between SGDP and M2GDP at the 5\% level. There is a strong correlation between CPSGDP and SGDP at the 5\% level of significance. Also, from the results presented in Table 2, we find significant correlations among proxies of financial development at conventional significance levels.

\section{Long-run and Short-Run Results}

The long-run and short-run dynamics are examined with the help of the error correction model. From the long-run elasticities result shown in Table 4, we find that the performance of the capital market (InMKTC) exerts a significant positive impact on the performance of the service sector in Nigeria. The result shows that a unit increase in capital market performance as captured by market capitalization increases output of the service sector by $0.103 \%$. This outcome is consistent with the finding of Kar and Mandal (2015), which finds a strong positive effect of stock market performance on output growth. Also, the result of Bekaert et al. (2005) corroborates this study's outcome. The paper asserts empirically that improving the performance of a stock market, a vital arm of the capital market, by liberalizing it would bring about a positive influence on the output. 
Table 5. Cointegration test result

\begin{tabular}{|c|c|c|}
\hline Test stat & Value & $\mathrm{K}$ \\
\hline F-stat & $\begin{array}{r}3.52 \\
\text { Critical value bounds }\end{array}$ & 3 \\
\hline Significance & $\mathrm{I}(0)$ bound & I(1) bound \\
\hline $10 \%$ & 3.47 & 4.45 \\
\hline $5 \%$ & 4.01 & 5.07 \\
\hline $2.5 \%$ & 4.52 & 5.62 \\
\hline $1 \%$ & 5.17 & 6.36 \\
\hline
\end{tabular}

Source: Authors' computation using Eviews software.

In the same vein, the effect of the size of the financial sector in Nigeria as represented by M2GDP, on service sector performance is positive and significant in the long run. This finding implies that the depth of the financial sector in Nigeria increases the performance of the service sector in the country. However, the impact of the ratio of credit to the private sector to GDP on service sector performance is weak and negative. This outcome corroborates the result of De Gregorio and Guidotti (1995) that found a negative relationship between private credit and longrun growth in Latin America. The paper suggests that poorly regulated financial liberalization could lead to a negative effect of financial intermediation on growth. Our finding indicates that loans from the deposit money banks (DMBs) in Nigeria to the private sector have not favorably impacted the performance of the service sector. The unfavorable business environment in Nigeria cannot be left out as a major cause of this. Some factors that impede productive activities of the sector include inadequate financial support for the service sector from the government, the rising cost of funds from the deposit money banks (DMBs), erratic power supply, gross shortage of other social facilities, poor training of the service providers, declining education system, etc. The existence of these impediments prevents service providers from efficiently maximizing the yield of credits taken from financial institutions.

Table 5 shows the result of the cointegration test. The result indicates no evidence of a long-run relationship between the variables of interest at the $5 \%$ level. The short-run result reported in Table 6 shows the short-run coefficients of the explanatory variables. This study finds that each of the proxies of financial development has an insignificant impact on service sector performance in the short term. Moreover, the error correction term coefficient $(-0.52)$ is significant and negative. This suggests that a deviation in the equilibrium level in the present year will be corrected in the following year by $52 \%$. Therefore, it takes about two years to reestablish the long-run equilibrium.

Table 6: Error correction estimation

\begin{tabular}{lcccc}
\hline Indices & ECM(-1) & D(InMKTC) & D(M2GDP) & D(InCPS) \\
\hline Coefficients & -0.52 & -0.02 & 0.01 & 0.06 \\
Std. error & 0.15 & 0.03 & 0.01 & 0.07 \\
T-stat & -3.40 & -0.76 & 1.20 & 0.86
\end{tabular}

Copyright (C) 2020, Journal of Advanced Research in Economics and Administrative Sciences (JAREAS), Under a Creative Commons Attribution 4.0 International License 
Source: Authors' computation using Eviews software.

\section{Conclusion and Suggestion}

This paper examined the relationship between financial development and the service sector performance in Nigeria. Our finding shows that capital market development contributes significantly and positively to the performance growth of the service sector in Nigeria. In support of this finding, Levine and Zervos (1996) argues that an advanced stock market offers various forms of financial services compared to the banking industry. The Nigerian Stock Exchange (NSE), which offers equity and debt instruments to investors, plays an important role in transmitting funds to the service sector in Nigeria as revealed by this study's outcome. The transmission channel favors the services sector.

We find a positive effect of monetary aggregates on the performance of the service sector. It is an indication that the increasing size of the financial sector in Nigeria is impactful to the service sector hence the increasing growth recorded in the sector. Certain sub-sectors of the service sector such as trade; information and communication; real estate; and professional, scientific and technical services; have performed relatively well over the years owing to the favorable financial space occasioned by expanding financial sector in Nigeria. The education industry is not left out. The increasing private sector investments recorded in secondary and tertiary schools across the country in recent times could not have been possible without financial contributions from the expanding financial sector and investments from the capital market. However, the findings of this paper indicate that credit from the financial institutions in Nigeria has not positively improved the service sector output. This outcome may not be unconnected to the rising business impediments in the macroeconomic environment in Nigeria, which is characterized by multiple taxations, high cost of import duties, erratic power supply, poor motorable roads, etc.

In light of the findings of this study, we recommend that the federal government should adopt effective fiscal measures to address rising fiscal inadequacies that tend to obstruct growth in the service sector. We believe that the proactive implementation of effective fiscal measures will address the rising cost of doing business in Nigeria.

\section{Acknowledgements}

We appreciate anonymous referees for their suggestions.

\section{Conflict of Interests}

The authors declare no conflict of interest.

\section{Funding}

For this research work, the authors did not receive funds from any organization. 


\section{References}

Allen, F., Qian, J., \& Qian, M. J. (2005). Law, finance, and economic growth in China. Journal of Financial Economics, 77, 57-116.

Amalu, H. I., Agbasi, L O., Ujam, O. J, \& Olife, L. U. (2020). Monetary policy approach to headline inflation control in Nigeria: Evidence from 1985-2018. International Journal of Research and Scientific Innovation (IJRSI), 7 (7), 2321-2705.

Audu, N. P., \& Okumoko, T. P. (2013). Financial Development and Economic Growth in Nigeria. European Journal of Business and Management, 5(19), 69-81

Bassey, G. E, \& Effiong, U. E. (2020). Financial deepening and economic growth in Nigeria: An empirical analysis. Social Sciences and Management International Journal, 1 (1), 93 112.

Bekaert, G., Harvey, C.R., Lundblad, C. (2005). Does financial liberalization spur growth? Journal of Financial Economics, 77 (1), 3-56.

Bittencourt, M. (2012). Financial development and economic growth in Latin America. Journal of Policy Modeling, 34, 341-355.

Boulila, G., \& Trabelsi, M. (2004). The causality issues in the finance and growth nexus: empirical evidence from Middle East and North African countries. Review of Middle East Economics and Finance, 2, 123-138

Calderon, C., \& Liu, L. (2003). The direction of causality between financial development and economic growth. Journal of Development Economics, 72, 321- 334.

De Gregorio, J., \& Guidotti, P. E. (1995). Financial development and economic growth. World Development, 23 (3), 433-448.

Dickey, D.A., \& Fuller, W.A. (1981). Likelihood ratio statistics for autoregressive time series with a unit root. Econometrica, 49.

Ductor, L. \& Grechyna, D. (2015). Financial development, real sector, and economic growth. International Review of Economics and Finance 37 (C), 393-405. doi:10.1016 /j.iref. 2015.01.001

Fan, J. J., Su, C. W., Lu, K. M., \& Doong, S. C. (2018). Is there a causal relationship between financial development and economic growth in China? Evidence from the bootstrap rolling-window approach. China: An International Journal, 16, 170-189

FinTech Association of Nigeria \& EY FinTech (2020). Nigeria fintech census: Profiling and defining the finTech sector. Nigeria FinTech Census Report, 1-20. Retrieved from https://www.proshareng.com/news/Fintech/FintechNGR-Launches-Nigeria-FinTechCensus-2020-Report/57209

Fry, M. (1995). Money, interest, and banking in economic development. Canadian Journal of Development Studies, 16, 312.

Greenwood, J., \& Smith, B. D. (1994). Financial markets in development and the development of financial markets. Journal of Economics, Dynamics and Control, 21, 145-181.

Gregorio, J. \& Guidotti, P. (1995). Financial development and economic growth. World Development, 23, 433-448.

Hasan, I., Wachtel, P., \& Zhou, M. (2009). Institutional development, financial deepening and economic growth. Journal of Banking \& Finance, 33, 157-170.

Copyright (C) 2020, Journal of Advanced Research in Economics and Administrative Sciences (JAREAS), Under a Creative Commons Attribution 4.0 International License 
Hashim, Y. A. (2011). Financial development and economic growth in Nigeria. International Journal of Management Science, 3 (3), 47-55.

Hermes, N., \& Lensink, R. (2004). Foreign bank presence, domestic bank performance and financial development. Journal of Emerging Market Finance, 3 (2), 207-229.

Iheanacho, E. (2016). The impact of financial development on economic growth in Nigeria: An ARDL analysis. Economies, 4 (4), 1-12. doi: 10.3390/economies4040026

Kar, S., \& Mandal, K. (2015). Banks, stock markets and output: Interactions in the Indian Economy. 1-22. Retrieved from https://www.researchgate.net/publication/265627862

King, R. G., \& Levine, R. (1993a). Finance and growth: Schumpeter might be right. Quarterly Journal of Economics, 108, 717-737.

Levine, R., \& Zervos, S. (1996). Stock market development and long-run growth. The World Bank Economic Review, 10, 323-339.

Liu, W., \& Hsu, C. (2006). The role of financial development in economic growth: The experiences of Taiwan, Korea, and Japan. Journal of Asian Economics, 17, 667-690.

Lucas, R. (1988). On the mechanics of economic development. Journal of Monetary Economics. 22, 3-42.

Madichie, C., Maduka, A., Oguanobi, C., \& Ekesiobi, C. (2014). Financial development and economic growth in Nigeria: A reconsideration of empirical evidence. Journal of Economics and Sustainable Development, 5(28), 199 - 208.

McKinnon, R. I. (1973). Money and capital in economic development. Washington, DC: The Brookings Institution.

Mollaahmetoğlu, E., \& Akçalı, B. Y. (2019). The missing-link between financial development and economic growth: Financial innovation. Procedia Computer Science, 158, 696-704.

Newey, W., \& West, K. (1987). A simple positive semi-definite, heteroskedasticity and autocorrelation-consistent covariance matrix. Econometrica, 55, 703-708.

Patrick, H. (1966). Financial development and economic growth in underdeveloped countries. Economic Development and Cultural Change, 14, 174-189.

Pesaran, M.H., Shin, Y. \& Smith, R. J. (2001). Bounds testing approaches to the analysis of level relationships. J. Appl. Econometrics, 16 (3), 289-326

Phillips, P.C., \& Perron, P. (1988). Testing for a unit root in time series regression. Biometrika, 75 (2), 335-346.

Schumpeter, J. A., 1912. The theory of economic development: an inquiry into profits, capital, credit, interest and the business cycle. Cambridge, MA: Harvard University Press.

Song, Y., Chen, B., Tao, R., Su, C., \& Umar, M. (2020). Too much or less? Financial development in Chinese marine economic growth. Regional Studies in Marine Science. https://doi.org/10.1016/j.rsma.2020.101324.

Thangavelu, S. M., \& Jiunn, A. B. (2004). Financial development and economic growth in Australia: An empirical analysis. Empirical Economics, 29, 247-260. doi: 10.1007/s00181-003-0163-7

Copyright (C) 2020, Journal of Advanced Research in Economics and Administrative Sciences (JAREAS), Under a Creative Commons Attribution 4.0 International License 
Fig. 1. Trend of ratio of private credit to GDP and the monetization ratio

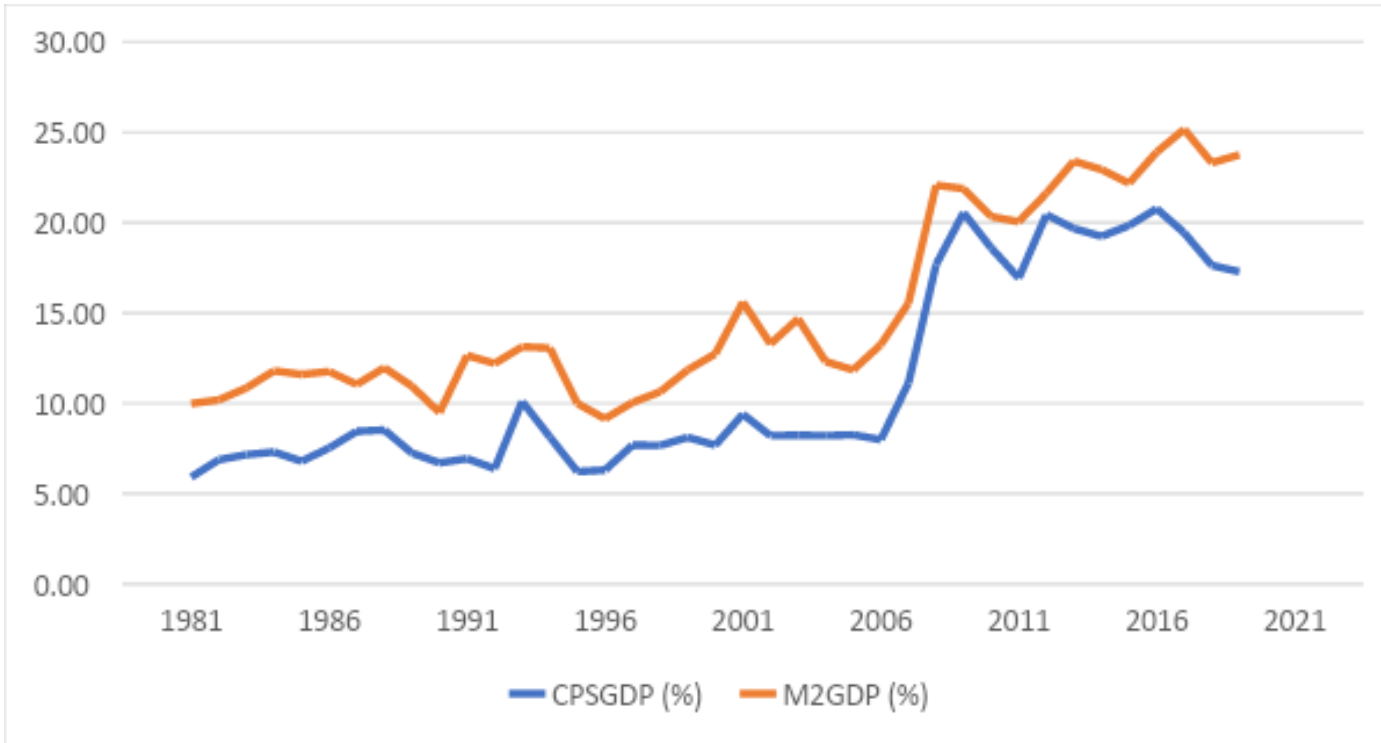

Fig. 2. Trend of ratio of service sector performance to GDP

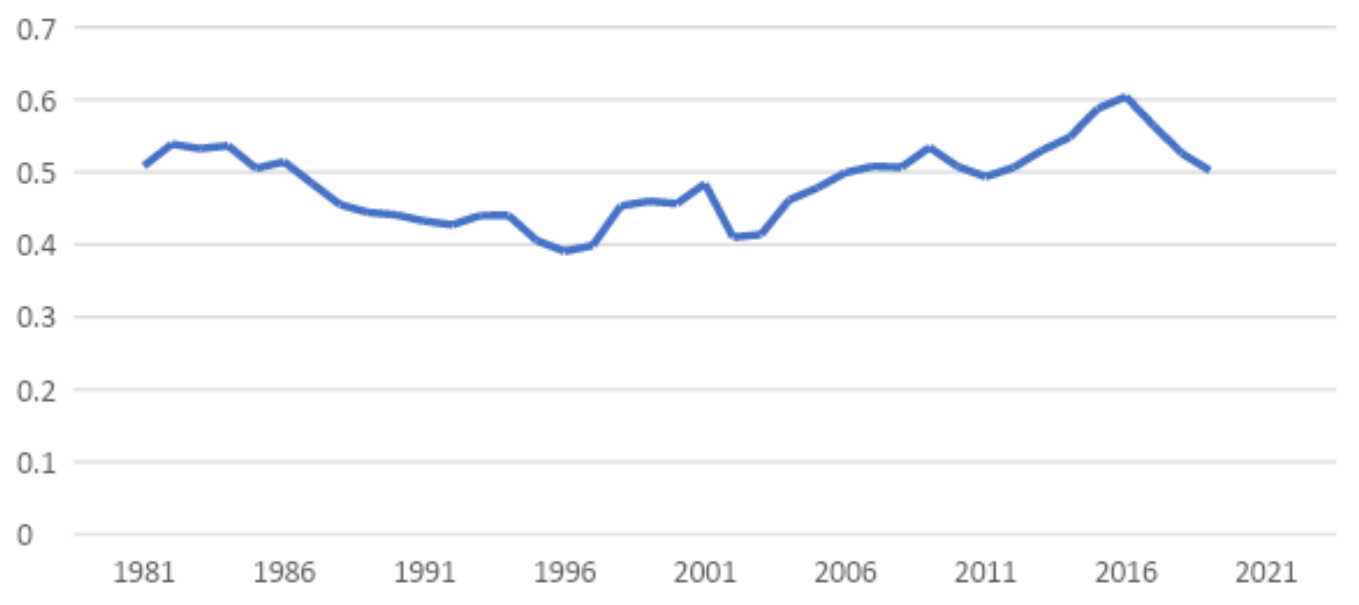

Fig. 3. Graphical presentation of market capitalization in Nigeria (1981-2019) 


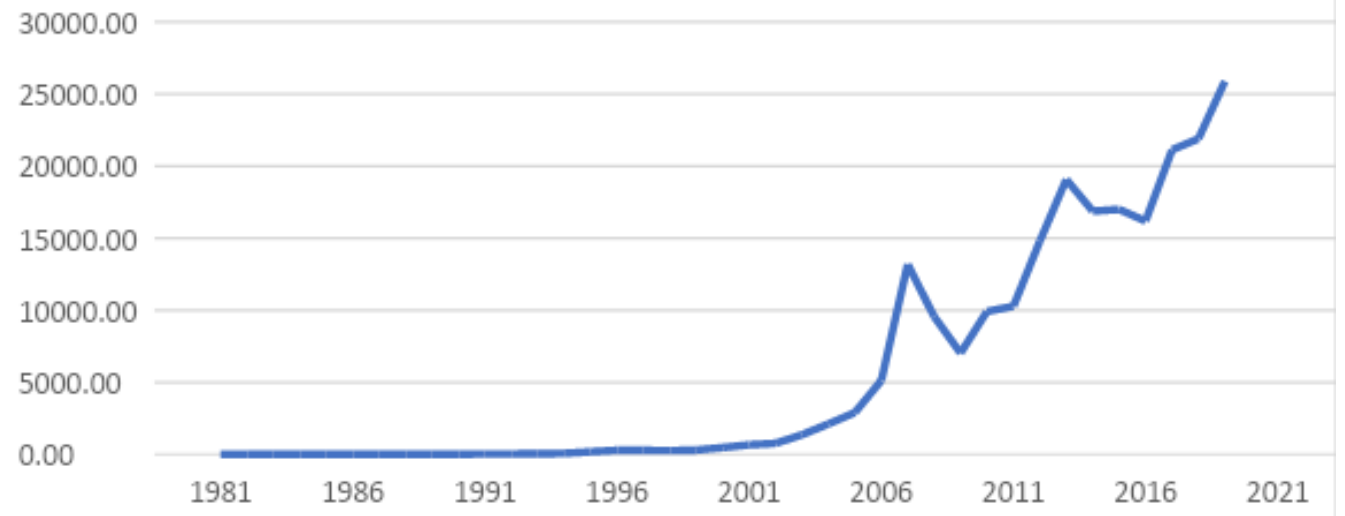

Unit: one billion naira 